\title{
Collaborative Governance: Managing Residential Areas In Malang Based on Public Private Partnership
}

\author{
Fitri Amalia Sari ${ }^{1}$, Sudarmo², Didik G. Suharto ${ }^{3}$, Nida Hanin Dary ${ }^{4}$ \\ ${ }^{1}$ Masters Program in Public Administration Department, Faculty of Social and Political Sciences, \\ Universitas Sebelas Maret, Indonesia (email: amalia7789@gmail.com), 2Public Administration Department, Faculty of \\ Social and Political Sciences, Universitas Sebelas Maret, Indonesia, ${ }^{3}$ Public Administration Department, Faculty of \\ Social and Political Sciences, Universitas Sebelas Maret, Indonesia, ${ }^{4}$ Masters Program in Public Administration \\ Department, Faculty of Social and Political Sciences, Universitas Sebelas Maret, Indonesia
}

\begin{abstract}
Slum areas are one of in Malang problems as the second largest city in East Java, especially along the Brantas River in the area of Jodipan village. According to Malang Local Government, Brantas River area is an area designated as a Green Space. Rearrangement of this area has not been done by the Local Government, and the area has turned into a densely populated area and Tourism Village. Guys Pro student group cooperates with PT. Indana Paint and supported by Malang Mural community are trying to promote the area. Although this violates existing regulations, the government still legalizes colorful villages as tourism areas. This is because the government has not been able to provide enough space to relocate citizen. Collaboration needs to be done by the Government with private sector to relocate citizen and rearrange tourism areas on the banks of Brantas River. PPP scheme will help government in handling costs and resources by the private sector. This research was conducted with descriptive qualitative and literature review methods. This research seeks to examine the innovations that the government can do in improving the governance of that area through citizen relocation and structuring of the Brantas river bank through PPP collaboration.
\end{abstract}

\section{Keywords:}

collaborative governance, Public-Private Partnership (PPP), Managing Area

\section{Introduction}

Slum settlements become a public problem that is still often found in big cities in Indonesia. One of the cases is in Malang City, which is the second-largest city in East Java. Slum settlements in Malang are scattered throughout the city area which are divided into 7 (seven) characteristics, namely the Dutch Colonial settlement area, the village premiere area, real estate area (small, medium, and large plot), residential area in the hinterland area, flat area , military settlement areas, and slum settlement areas (Susanto, Endarto \& Ledy, 2016). Slum settlements in Malang can be found along the Brantas River, more precisely in Kelurahan Kesatrian, 
Kelurahan Jodipan at Blimbing Sub-district and Embong Brantas Village in Kelurahan Mergosono, and also slum settlements on the Ciptomulyo Kelurahan railroad. In general, the condition of slum buildings in Malang is permanent, only a few parts are made of semipermanent material.

According to the Head of Malang City Planning, Research and Development Agency (Barenlitbang), Wasto, said that the area of slums in Malang reached 603 hectares spread across 29 villages (Murdaningsih, 2015). Data from Malang City Government of Blimbing Subdistrict as of December 2014 shows that Jodipan Village has an area of 49 hectares with a population of 13,272 people, so the population density (soul/hectare) is 270.8 . The population density assessment category between 194.3-270.8 shows high density, so it can be concluded that Jodipan Village is included in the high-density category which is an indicator of slum areas (Rofiana, 2015). Based on Malang City Regulation Number 04 of 2011 concerning RTRW of 2010-2030 Article 48 states that the Malang City Government is obliged to make settlement arrangements in the riverbanks that flow through Malang City. The development of riverbanks which has been referred to be slum areas is actually included in the draft Malang City Regulation No. 04 of 2011 concerning Spatial Planning for Malang City Region 2010-2030. The condition of settlements on the banks of the Brantas River in Jodipan Village has made it one of its own problems with the environment in which people live, because the area is prone to disasters, both tornados and landslides (Sukarelawati, 2016).

According to the Malang City Government, the Brantas River area is an area designated as a Green Open Space (RTH) which has a building demarcation boundary line that has been regulated in the RDTR and RTRW, and should not be used as a place to live because it could endanger its inhabitants. But the fact is, the Brantas River is one of the densely populated areas in Malang. Malang City Government has a target or program to overcome the problems of slums in the area. One of them is by rearranging and moving the residents to flats that have been provided by the Government which is located in the Kedungkandang City of Malang. But the government was unable to overcome these problems in a fast period of time without collaboration with the private sector. That is because handling slum problems is not just about physical improvement but also about how to improve the standard of living of the people in the 
area. Slum settlements have the potential to be developed and managed into tourist areas through partnerships between the government and the private sector. In the current era of decentralization, local governments are the spearhead of development. Besides, the private sector can also be included through the Corporate Social Responsibility (CSR) program. At present, there have been many CSR programs that have been involved in fixing slum areas.

The rearrangement had not yet been carried out by the Government because the slum settlements in the Brantas Riverbanks area of Jodipan Village turned into a Tourism Village called a Kampung Warna Warni. Kampung Wisata Warna-Warni begins with the initiation of a group of students who are members of Guys Pro from the University of Muhammadiyah Malang who see that the landscape of the Juanda Village that is quite good to be painted in colors like Code Tourism Village located in the Yogyakarta area. The Guys Pro student group teamed up with PT Indana Paint and was supported by the Malang Mural community to improve the village. Kampung Warna-Warna is the first tourist village in the city of Malang on the banks of the Brantas River. Located in RW 02, precisely in RT 06, 07 and 08, Juanda Village, Jodipan Village, Belimbing District, Malang City. Kampung Warna-Warna is an area that was once considered a "slum area" and is now a location that is visited by many tourists (Widianto, 2016).

This made the Government initiate the construction of a new Tourism Village by cooperating with PT Indana Paint and inviting the community to manage the area. The new tourist village is called Buk Gluduk Village (now called Tridi Tourism Village) which is located across from Juanda Village and is also located on the riverbank which should also be relocated and designated as green space. But the problem is that the village is an area that is still prone to disasters. This was proven by the disaster that happened to one of Kampung Warna-Warni residents whose house collapsed due to not being able to withstand the flow of rain that hit the sidewall of his house. At that time, rain puddles rose to the surface of residents' houses because the drainage under the village was blocked. Sutiaja (2016) who was the deputy mayor of Malang at the time explained that the houses on the banks of the Brantas River were not designed to withstand the flow of water during heavy rains. So that if there is a flood, houses in the area have the potential to collapse/collapse. The condition occurred because the village 
became a place for the flow of rainwater from several areas in Malang to the Brantas River. This is dangerous for the community because the village has become a tourist magnet in the city of Malang. Besides, there is a negative social impact, namely the occurrence of abuse of residential roads that are used as merchant stalls. Environmental impact can be seen from the physical changes in the area both inside and outside the tourist area.

Collaboration needs to be done by the Government, the private sector and the community to improve regional governance through the relocation of citizens and the arrangement of the Brantas riverbank through the collaboration of Public-Private Partnership. Public-Private Partnership (PPP) can be broadly defined as collaboration between the public sector and private entities that share costs, risks, and benefits to jointly plan and implement activities towards a common goal (Spielman et al., 2010). Collaborative initiatives aim to overcome obstacles, such as market failures, institutional constraints, and systemic weaknesses, to produce agricultural knowledge and technology (Spielman et al., 2007). Spielman et al. (2007) have stressed the importance of partnerships to clearly define problems, solutions, and needed resources, and have effective monitoring of decision making and available communication mechanisms. Similarly, as revealed by Glasbergen (2011) that the Public-Private Partnership should be a tool to promote sustainable development, by reconciling seemingly opposite policy objectives, such as policies to enhance rural development, while at the same time preserving natural resources, such as biodiversity, forests, fish and water resources (Glasbergen, 2011).

Research on partnerships in the management of slum settlements was conducted by Chauhan \& Lal (2016). In his journal explaining public and private partnerships for the development of the poor in the city in the Slum Network Project at Ahmedabad. In December 1994, Himanshu Parikh, an environmental and infrastructure professional, met Sanjay Lalbhai, MD, Arvind Mills. Parikh showed Arvind's management team that remarkable urban improvements could be achieved through a slum network strategy demonstrated through the Indore Habitat Project sponsored by the British government. Lalbhai and his team see the project as the best way to improve the quality of life in Ahmedabad. The poor must improve the skills of the unskilled so that the unskilled can create good job opportunities for themselves. To 
achieve this, they strongly believe that the government, NGOs, and the corporate sector must work in partnership where the government plays the role of facilitator (Chauhan \& Lal, 2016).

Ebakpa, Gobo, Ngah \& Abam (2017) explained the same thing, that the provision of adequate accommodation is a big challenge for governments in developing countries. This is a common phenomenon in urban centers in developing countries where most homes are in deplorable conditions. There is no basic sanitation in the city centers because they do not have flush toilets. Some available flush toilets are channeled to seasonal streams. Most homes do not have a clear kitchen area and healthy waste disposal methods. These cities lack good access to roads and management of solid waste that is not environmentally friendly which creates various health problems for citizens. Ebakpa, Gobo, Ngah \& Abam (2017) recommend using the in-situ method of slum rehabilitation housing which can be applied through Public and Private Partnerships to improve the quality of houses in the main slum areas in Yenagoa. This is done by entering into an agreement between the property owner, the Real Estate investor and the Bayelsa state government using the Slum Comprehensive Rehabilitation Scheme (Ebakpa, Gobo, Ngah \& Abam, 2017).

This study aims to find out how partnerships or collaborations are conducted between the public and private sectors in improving regional governance through the relocation of residents and the realignment of the Brantas riverbank.

\section{Methods}

This study uses a qualitative method with a literature review approach. This type of literature review is conducted to evaluate the state of knowledge about a particular topic. A literature review provides the basis for constructing new conceptual models or theories and can be assessed when aiming to map the development of a particular field of research over time (Snyder, 2019). His research was conducted with a literature review study method from books, articles, and journals on Collaborative Governance, Public-Private Partnership, regional spatial management, the collaboration between the government and the private sector and the community, as well as news adapted from websites related to Public-Private Partnerships and Slum settlements. Data is collected from journal articles, country reports and previous research 
where there are several choices of accredited journal articles, both national and international, to make it easier for researchers to restrict articles. Then the data that has been collected is processed by the Collaborative Governance theory. This study also uses keywords as a way to facilitate the search for relevant articles, namely collaborative governance, Public-Private Partnership (PPP), Managing Area, and Slum Tourism. Thus generating new data about the needs of research subjects which are then analyzed again to design strategic planning as a form of innovative solutions for sustainable development and spatial management in slum areas.

To compile this research, researchers have 3 (three) problem formulations. The formulation of the problem will help to limit the research and to be the basis for the preparation of this research. There is the following formulation of the problem presented by researchers, namely how is the collaboration carried out by the government, private sector and the community in managing the area?

\section{Result and Discussion}

Based on data obtained through journal articles and news shows that there is a collaboration between the government, the private sector and the community in the management of slum areas that have been compared to tourist attractions in Malang. Kampung Wisata Warna-warni Jodipan begins with the initiation of a group of students who are members of Guys Pro from Muhammadiyah University of Malang who see that the Juanda Village landscape is pretty good when painted in colors like Code Tourism Village located in the Yogyakarta area. The Guys Pro student group teamed up with PT Indana Paint and was supported by the Malang Mural community to compare the village. Since then, the village was ogled by tourists both local and foreign tourists.

The concept of collaborative governance presented by Gash (2016) explains that Collaborative Governance is characterized as a collection of knowledge and resources among a broadly inclusive set of actors with an interest in the problems faced (eg Citizens' groups, policymakers, natural resources or other industries, indigenous groups). In general, collaborative governance is a general term that encompasses a variety of public administration topics including intergovernmental and interagency collaboration, regionalism, cross-sector 
partnerships, public service networks, consensus building, and public engagement (Emerson, Nabatchi, \& Balogh, 2012). The essence of collaborative governance is socio-political involvement between individuals and organizations with varying degrees of autonomy, which is a more effective way to overcome modern society's need and realize shared goals beyond whatever they have so far been able to achieve themselves (Donahue, 2004). In a narrower sense, collaborative governance is usually used to describe how public institutions partner with non-state stakeholders in the process of making public policy decisions (Ansell \& Gash, 2008). Another definition expressed by Gash (2016) is that Collaborative Governance is limited to actors or more narrow functions (Gash, 2016). Collaborative Governance, in some definitions only includes partnerships that involve public institutions in serving public goals (Ansell and Gash, 2008). The keys to collaborative governance include collaborative initiatives, collaborative culture, community vision, trust, consensus rulemaking, and collaborative network structures; while major challenges can include pluralism, activism, institutional practices, and transaction costs (Bang \& Kim, 2016). To start the collaboration, leadership is needed to take sides and start a forum for government and non-government stakeholders (Emerson et al., 2012).

In this case, collaboration is carried out by the Government and the community to manage and develop Tridi Tourism Village and Jodipan Tourism Village in order to become an advanced and feasible tourist area. As previously explained, Jodipan and Kampung Tridi are the slum areas located on the banks of the river and are not suitable for habitation but should be used as Green Open Space. Although the physical condition of the houses in Jodipan has been improved, the main problem of the village is that sanitation has not been able to be overcome. There are still many residents in the village that don't have toilets, so residents must take turns using the toilet. Besides, there is still a lack of awareness about the importance of maintaining cleanliness. Some residents still often throw trash in the river. Until then some garbage bins are provided by the Government in that place and then the trash will be transported every day by the janitor. The cost to transport the garbage is obtained from the village entrance ticket, which amounts to Rp. 3,000 per person. In addition to waste of money, money is also used for environmental care (BBC.com, 2016). Handling slum settlements, Malang City Government gets funding from the Ministry of Public Works and Public Housing in the amount of 30 billion 
rupiahs. The funds are used to improve sanitation, street lighting, drainage and drinking water supplies (BBC.com, 2016). So that the Government and the community must work together to manage and develop the area so that it is suitable for habitation.

Several attempts were made by the government to develop the area, such as supporting the development of Tridi Tourism Village and Jodipan Tourism Village. This was manifested in several forms, the first, intensifying marketing and promotion by giving a role in developing Tridi Tourism Village and Jodipan Tourism Village (Nisa, Afifuddin, Suyeno, 2019). Promotion is carried out by the Culture and Tourism Office of Malang City through social media. The more posts about Jodipan and Kampung Warna Tridi villages, the more tourists or visitors who come to these tourist destinations, both from local and foreign. In addition to posting, many pamphlets about Kampung Warna-Warni Jodipan and the tourist village of Tridi as a tourist area in Malang are also included as the top destinations of Malang. Not only the Culture and Tourism Office is actively promoting, the community and the tourism village management parties are also involved in promoting the tourism potential.

Secondly, the Government is doing branding, building and raising the name of the Kampung Warna-Warni Jodipan and Tridi Village Tourism. By carrying out the theme of beautiful Malang Malang Culture and Tourism Office of Malang City can attract the interest of tourists to visit tours in Malang by making Jodipan Tourism Village and Tridi Village as one of the icons of Malang City (Idris, Ati, Abidin, 2019). By participating in international scale exhibition events, many tourists come to Malang. Besides being included in exhibitions, the Culture and Tourism Office of Malang City also made a book about the charm of the thematic village of Malang. In the book of the charm of thematic villages, Jodipan Tourism Village and Tridi Village are included as top destinations owned by Malang. With the charm of the thematic village, Malang City can attract tourists to visit Jodipan Tourism Village and Tridi Village.

The third effort is the government conducting a comparative study to improve tourism development. Furthermore, socializing the development of the Tridi Tourism Village and Jodipan Tourism Village in order to improve the characteristics of the tourist village. And then provide information on the use of used goods. The people of Jodipan are empowered to form craft centers so that the continuity of Kampung Warna-warni Jodipan continues to be 
sustainable through the creativity guidance program. The community is also taught to make food or beverage products that can later be sold to visitors or tourists. Like how to make ice cream and mushroom processing. The issue of ice cream making and mushroom processing is done at the residents' homes at night, this is based on an agreement between the residents and the party who runs the creativity guidance program.

In addition, the government is also improving facilities in developing Tridi Tourism Village and Jodipan Tourism Village to provide services that can increase satisfaction with the needs of tourists that visiting the village. Now Kampung Warna-Warni Jodipanhas 4 public toilets which are located in residential areas that can be used by the community and visitors or tourists of Kampung Warna Warni Jodipan. Public toilets around the field area are quite attractive. Public toilets are decorated with colorful vertical stripes so that visitors often use them as a spot to take pictures. Other facilities provided by the Government are open spaces in Kampung Warna Warni Jodipan in the form of fields and riverside areas. Part of the utilization of open space in the Kampung Warna Warni area is used by local residents to open shanties at any point. Then there is also a mini library but unfortunately, it does not function as it should, because the books provided are less attractive to tourists. Tourists who are around the mini library area tend to function in this area as a background photo rather than to read a book that has been provided. Other facilities are in the form of two P3K boxes scattered in Kampung Warna Warni Jodipan area and can be used by tourists who experience minor injuries. However, the location of the first aid kit is not easy to reach by tourists and the medicines stored in the first aid kit are limited.

Now there are new facilities in Kampung Warna Warni Jodipan and Kampung Tridi namely the Glass Bridge which is intended for the surrounding community and visitors or tourists. The glass bridge has a length of 25 meters with a width of 1.5 meters and a height of 9.5 meters from the plain that can connect Kampung Warna Warni Jodipan and Tridi Village. To facilitate access and kinship between the Kampung Warna Warni village and Tridi village where the two villages are located opposite and separated by the Brantas River flow. Before the bridge was built, tourists who wanted to enjoy both sides of the village had to climb dozens of steps and rotate through the Brantas Bridge (Replubika.co.id, 1017). he bridge construction idea 
came from the City Government of Malang in collaboration with the University of Muhammadiyah Malang (UMM) and PT Inti Daya Guna Various Colors (Indana). The glass bridge was designed by two Civil Engineering students at the University of Muhammadiyah Malang. While PT Indana contributed as a buffer for the construction of the glass bridge. The cost spent on the construction of the glass bridge is not small, about six tons of paint channeled to beautify Kampung Warna Warni Jodipan and Kampung Tridi Village. The glass bridge that stands on the Brantas River is also the first glass bridge in Indonesia. The bridge can be used by two lanes or two people who walk past each other and can accommodate a load of $500 \mathrm{~kg}$ (Jatim.tribunnews.com, 2017).

Efforts made by the government towards the management and development of Kampung Warna Warni Jodipan and Kampung Tridi are supported by the community using the community participating in it. Community participation is manifested in the form of maintaining village infrastructure. The role of infrastructure does not only affect tourism development but also in the field of tourism. Infrastructure plays a very important role in encouraging the quality of tourism itself as well as the surrounding environment (Nisa, Afifuddin, Suyeno, 2019). Then the maintenance of the paint treatment in the Tridi village andjjodipan village. Maintenance can be done once a month so that people do not get bored with spot images that are in Kampung Warna Warni Jodipan and Tridi villages with examples of changing images with other images, changing other colors to look different from before (Idris, Ati, Abidin, 2019). The upgrading of photo spots by the Tridi Village community and the Jodipan Tourism Village community is one form of development carried out by the local community as a service provider. The more frequent updates to the photo spots will increase the number of visitors or tourists who come.

The interesting thing that distinguishes the two tourist villages with other tourist attractions is that visitors will find some handicrafts and creativity from the PKK associations and mothers. In Tridi Village, visitors who come are given key chains as souvenirs which are the hand of the PKK Kampung Tridi women. Existing souvenirs are a form of creative ideas from PKK Kampung Tridi women who make key chains with various characters (Idris, Ati, Abidin, 2019). Excavation of creative ideas continues to be done by the Tridi Village 
community. Meetings are held once a week to discuss developments by gathering ideas from all members. Creative and interesting ideas are used to update photo spots to replace old pictures. In contrast to what the PKK women in Tridi village did, in Jodipan Tourism Village, they always held training in the use of used items to make decorations at their tourist attractions. Once a month they hold training which is attended by PKK women by bringing presenters from the Kelurahan and students (Idris, Ati, Abidin, 2019). Every training that is held always produces a lot of decorations which are then installed in every corner of the tourist attractions which are good to be a place to take pictures by visitors. Besides, the community also maintains cleanliness in Kampung Warna Warni Jodipan and Kampung Tridi. Care and cleaning must be considered given that the village is one of the tourist attractions in Malang, which is visited by tourists. Cleanliness is very important so that tourists who visit feel comfortable and clean (Nisa, Afifudin, Suyeno, 2019). Every 6 months, people do the painting. Painting is carried out by the community as a service provider is done every change of season so that the paint does not fade or dirty.

Sustainability and hygiene activities are not only carried out by the government and the community, but also by private parties. In commemoration of Earth Day which falls on April 22, one of the hotels in Malang, namely THE $1 \mathrm{O} 1$ Hotel Malang OJ did a village clean in Kampung Warna Warni Jodipan. Several people clean up on the banks of the Brantas river by picking up trash that is littered in the area. Some of them even cleared the colorful walls of the village walls to make the colors brighter. This activity is a CSR activity carried out by THE $1 \mathrm{O} 1$ Malang Hotel OJ as a form of environmental awareness around Kampung Warna Warni Jodipan and aims to work together to protect the environment and public facilities in the tourist area of Kampung Warna Warni Jodipan (JawaPos.com, 2019 ).

Another form of collaboration undertaken to manage and develop tourism areas in Kampung Warna Warni Jodipan and Tridi villages is a collaboration carried out by the Ministry of Public Works and Public Housing (PUPR) with the Regional Government (Pemda) to intensify the City without Slums (Kotaku) Program to improve the quality of the region slums in urban areas. The activity was carried out through the Directorate General of Human Settlements, which involved the community aimed at increasing access to basic infrastructure 
services in urban slums. In the 2015-2018 period, the Ministry of PUPR had handled 23,407 hectares and in 2019 it was targeted to be 13,704 hectares. The Kotaku program is a communitybased infrastructure development program for. The scope of work will be in the form of repair of drainage canals, improvement of environmental roads, construction of communal biophilic septic tanks, and grant of garbage carts and garbage transport motors for waste management. The total budget for environmental management in one of the thematic villages in Malang was Rp1 billion through the 2018 State Budget (Medcom.id, 2019).

Kampung Warna Warni Jodipan and Tridi villages have been managed quite well but the village is located on a riverbank that is not suitable as a place to live because of the potential for disaster. This is evidenced by the disaster that happened to one of Kampung Warna Warni Jodipan residents whose house collapsed due to not being able to withstand the flow of rain that hit the sidewall of his house. At that time, rain puddles rose to the surface of residents' houses because the drainage under the village was blocked. Sutiaja (2016) who was the deputy mayor of Malang at the time explained that the houses on the banks of the Brantas River were not designed to withstand the flow of water during heavy rains. So that if there is a flood, houses in the area have the potential to collapse/collapse. The condition occurred because the village became a place for the flow of rainwater from several areas in Malang to the Brantas River. This is dangerous for the community because the village has become a tourist magnet in the city of Malang. Besides, there is a negative social impact, namely the occurrence of abuse of residential roads that are used as merchant stalls. Environmental impact can be seen from the physical changes in the area both inside and outside the tourist area.

The management of slums has many positive impacts on the people of Kampung Warna Warni Jodipan and Tridi Village, including being able to improve and support the economic conditions of the people in the village and being able to improve conditions of slum punishment to become clean and beautiful tourist villages. Relocation of the community to flats failed and then camouflaged into thematic villages. However, these conditions are only temporary or short term. Long-term solutions are needed to overcome the real problems of Kampung Warna Warni Jodipan and Tridi villages. Relocation is still carried out by looking at several considerations and based on government regulations. Besides the rearrangement in the 
village is also needed especially in the river's edge. To realize this, a Public-Private Partnership (PPP) based collaboration or partnership is needed.

The Public-Private Partnership makes it possible to form and develop a system of longterm economic and organizational relationships that is mutually beneficial between public authorities, local governments, social institutions and the private sector (Vertakova \& Plotnikov, 2014). Public-private partnership (PPP) can be broadly defined as collaboration between the public sector and private entities that share costs, risks, and benefits to jointly plan and implement activities towards a common goal (Spielman et al., 2010). The aim of collaborative initiatives is to overcome obstacles, such as market failures, institutional constraints, and systemic weaknesses, to produce agricultural knowledge and technology (Spielman et al., 2007) Spielman et al. (2007) have stressed the importance of partnerships to clearly define problems, solutions, and needed resources, and have effective monitoring, decision making and communication mechanisms available. These factors are very important for achieving trust between public and private partners (Poulton and Macartney, 2012) and in coordinating knowledge among many actors (Spielman et al., 2007). According to the World Bank (2003), Public-Private Partnership refers to arrangements, usually in the medium to long term, between the public and private sectors where part of the service or work under public sector responsibility is provided by the private sector, with clear agreements about a common goal for the delivery of public infrastructure and or public services. OECD (2008) defines Public-Private Partnership as a long-term agreement between the government and private partners where the purpose of providing government services is in line with the profit objectives of the private partner (OECE, 2008).

The term Public Private Partnership originated in the United States in the early 20th century, initially relating to the joint delivery of public and private sector education programs, and then in 1950 in connection with a similar approach in the United States in the utility sector. In the 1960s the term came into widespread use with reference to public-private joint ventures for urban renewal. It is also used in the United States to refer to the provision of publicly funded social services by non-public sector bodies, often from the voluntary (non-profit) sector, as well as public funding for private-sector research and development in fields such as 
technology (Yescombe \& Farquharson, 2018). Public-Private Partnership is defined as cooperation that takes place between the public and private sectors in working towards shared goals through the mutually agreed-upon division of labor and shared resources and sharing risks and benefits (Buseand Walt, 2000).

The concept of partnership stems from the idea that the government (itself) fails to deliver collective goods such as sustainable development and that there is a need to seek support from other sectors of society. Through the partnership process, it is assumed that the public and private sectors can benefit by combining their knowledge and expertise but also financial and other resources, to deliver collective goods in more efficient ways. Therefore, the Public-Private Partnership is seen as an alternative to privatization (Hodge and Greve, 2007) Public-Private Partnership can involve infrastructure projects. In this sense, it refers to an arrangement whereby the government declares its needs for capital-intensive and long-lived infrastructure and desired facilities are built using a complicated combination of government and (mostly) private financing and then operated by private entities under a long-term franchise, contract, or lease (Savas, 2000).

The Public-Private Partnership has been pursued as an important tool to contribute to sustainable development activities. In its generic form, the Public-Private Partnership can be defined as arrangements for collaborative arrangements in which actors, from two or more layers of society (state, market and or civil), are involved in a hierarchical process, and through which these actors strive to achieve sustainability goals. Whereas Weihe (2006) classifies PublicPrivate Partnership insensitive categories, based on their approach: local regeneration, policy, infrastructure, development, and governance. Local regulations and policy approaches are very similar, both involving initial definitions of the concept of Public-Private Partnership which include policy changes in the environment, economic reform, development, and institutional structure (Van, Francken, Leroy, 2007). According to Glasbergen (2011), Public-Private Partnership should be a tool to promote sustainable development, by reconciling seemingly opposite policy objectives, such as policies to enhance rural development, while at the same time preserving natural resources, such as biodiversity, forests, fish and resources water power (Glasbergen, 2011). 
The concept of Public-Private Partnership has been applied in various countries, one of which is in Malaysia. A study conducted by Ismail \& Harris (2014) explained that the PublicPrivate Partnership (PPP), as a procurement method to deliver public sector projects has been used throughout the world including Malaysia. In a broad sense, the Public-Private Partnership includes any arrangement between the public sector and the private sector to provide public services. The involvement of the private sector in providing public goods and services is not new in Malaysia. With the introduction of the Malaysian Policy Founded in 1983; cooperation or partnerships between the public and private sectors have been encouraged to drive Malaysia's economic growth (Ismail \& Harris, 2014).

Public-Private Partnership has become a popular tool for managing rural development in a European context. Public-Private Partnership is often presented as a significant solution to increase the effectiveness (capacity of problem-solving) and the legitimacy of sustainable rural governance in terms of participation and accountability. In Sweden, where the Public-Private Partnership has played a marginal role, because of their European Union cohesion policy now acquires land as a model for governance and management of natural resources in rural areas. Then the same thing was expressed by Absalyamov (2015) that the Public-Private Partnership (PPP) is the involvement of the private sector by the authority based on contracts and provisions for compensation of costs, risk sharing, obligations, and competencies for the implementation of effective and qualitative objectives relating to the public economic secto . The main thing in public-private partnerships is adherence to the balance of interests. At the same time, private investment in cultural monuments is considered a form of social business responsibility. They are taken into account in social reports and image capitalization of companies involved in the revival of cultural values (Absalyamov, 2015).

\section{Conclusion}

The government, private sector, and community have collaborated in managing and developing slums that have been compared to tourist improve in Malang. Some of the attempts were made by the Government to manage and develop villages, the first of which was to promote Tridi Village and Jodipan Village. Both governments carried out branding in 
developing and raising the name of Kampung Warna Jodipan. Third, the government promoted the development of the Tridi Village and Jodipan Village. Efforts made by the government are supported by the community with community participation. Community participation is realized in the form of maintaining infrastructure and maintaining facilities in the village. Preservation and hygiene activities are not only carried out by the government and community, but also by the private sector. One of the hotels in Malang namely THE 101 Malang Hotel OJ did the cleaning in Jodipan Colorful Warriors using CSR funds. Another form of collaboration was carried out by the Ministry of Public Works and Public Housing (PUPR) with the Regional Government (Pemda) to intensify the Slum City Program (Kotaku) to improve the quality of slums in urban areas.

Management of slums has many positive impacts on the community, but this condition is only temporary or short term. Long-term solutions are needed to overcome the real problems of the colored tourism villages in the villages of Jodipan and Tridi. Relocation is still done by taking into account several considerations and based on government regulations. Also, rearrangement in the village is also needed, especially on the river bank. To realize this, collaboration or partnerships based on Public-Private Partnerships are needed.

\section{References}

\section{Books}

Donahue, J. (2004). On collaborative governance. Cambridge: John F. Kennedy School of Government, Harvard University

Gash, A., 2016. Collaborative Governance. Handbook on Theories of Governance

OECD (2010). Dedicated Public-Private Partnership Units: A Survey of Institutional and Governance Structures, OECD Publishing

Savas, E.S., (2000). Privatization and Public-Private Partnerships, Seven Bridges Press: New York

\section{Jurnal}

Absalyamov, T. (2015). Tatarstan Model of Public-Private Partnership in the Field of Cultural Heritage Preservation. Procedia - Social and Behavioral Sciences, 188, 214-217 
Ansell, C., \& Gash, A. (2008). Collaborative governance in theory and practice. Journal of Public Administration Research and Theory, 18(4), 543-571

Bang, M. S., \& Kim, Y. (2016). Collaborative governance difficulty and policy implication: Case study of the Sewol disaster in South Korea. Disaster Prevention and Management, 25(2), 212-226.

Bjärstig, T., \& Sandström, C. (2017). Public-private partnerships in a Swedish rural context-A policy tool for the authorities to achieve sustainable rural development? Journal of Rural Studies, 49, 58-68

Bovaird, T., 2004. Public-private partnerships: from contested concepts to prevalent practice. Int. Rev. Adm. Sci. 70 (2), 199-215

Buse, K., Walt, G., 2000. Global public-private partnerships: Part I-a new development inhealth? Bull. World Health Organ. 78 (4), 549-561.

Chauhan, U., and Lal, N., (1999). “Public-Private Partnerships for Urban Poor in Ahmedabad: A Slum Project." Economic and Political Weekly, vol. 34, no. 10/11, pp. 636-642. JSTOR, www.jstor.org/stable/4407736

Emerson, K., Nabatchi, T., \& Balogh, S. (2012). An integrative framework for collaborative governance. Journal of Public Administration Research and Theory, 22(1), 1-29

F. Ebakpa, A. E. Gobo, S. A. Ngah", T. K. S. Abam, (2017). “Public-Private Partnership Arrangement in In-Situ Housing for Slum Rehabilitation in Yenagoa, Bayelsa State, Nigeria." Journal of Environmental Protection, 2017, 8, 2152-2219 ISSN, pp. 1530-1540

Glasbergen, P., 2011a. Understanding partnerships for sustainable development analytically: the ladder of partnership activity as a methodological tool. Environ. Policy Gov. 21 (1), $1 \mathrm{e} 13$

Hodge, G. A., \& Greve, C. (2007). Public Private Partnerships: An International Performance Review. Public Administration Review, 67(3), 545-558

Idris, Ati, Abidin. (2019). Peran Pemerintah Dalam Pengembangan Wisata Kampung Jodipan Dan Kampung Tridi (Studi Kasus Di Kelurahan Jodipan Dan Kelurahan Kesatrian Kecamatan Blimbing Kota Malang). Jurnal Respon Publik Volume 13, No. 4, Tahun 2019, Hal 68-77 Issn 2302-8432 68 
Ismail, S., \& Harris, F. A. (2014). Challenges in Implementing Public Private Partnership (PPP) in Malaysia. Procedia - Social and Behavioral Sciences, 164, 5-10.

Marana, P., Labaka, L., \& Sarriegi, J. M. (2017). A framework for public-private-people partnerships in the city resilience-building process. Safety Science.

Marshall, F., Dolley, J., (2019). Transformative innovation in peri-urban Asia. Science Policy Research Unit (SPRU). 983-992

Mokodongan. Budi Kurniawan, Rieneke L. E, dan Hendriek H. Karongkong, 2014, “Identiikasi Pemanfaatan Kawasan Bantaran Sungai Dayanan di Kota Mobagu", Sabua Vol. 6, No. 3

Morano, P., \& Tajani, F. (2018). Saving soil and financial feasibility. A model to support publicprivate partnerships in the regeneration of abandoned areas. Land Use Policy, 73, 4048.

Nisa, Afifuddin, Suyeno. (2019). Pengembangan Kampung Wisata Jodipan Dan Kampung Wisata Tridi Oleh Pemerintah Kota Malang Dalam Meningkatkan Status Sosial Dan Ekonomi Masyarakat (Studi Kasus Di Kelurahan Jodipan Dan Kelurahan Kesatrian Kecamatan Blimbing Kota Malang). Jurnal Respon Publik Issn: 2302-8432 Vol. Xiii No. 1 Tahun 2019 Hal 24-33 29

Poulton, C., Macartney, J., 2012. Can public-private partnerships leverage private investment in agricultural value chains in Africa? A preliminary review. World Development 40 (1), 96109

Rofiana. Vivian, 2015, “Dampak Pemukiman Kumuh terhadap Kelestarian Lingkungan Kota Malang", IJPA Vol. 02, No. 01

Snyder, H. (2019). Literature review as a research methodology: An overview and guidelines. Journal of Business Research, 104, 333-339. doi:10.1016/j.jbusres.2019.07.039

Spielman, D.J., Hartwich, F., von Grebmer, K., 2010. Agricultural research, public-private partnerships, and risk management: Evidence from the international agricultural research system. Asian Biotechnology and Development Review 12 (1), 21-50 
Susanto. Endarto Budi dan Ledy Vithalia Therik. 2016, "Faktor Penentu Bertempat Tinggal pada Kawasan Kumuh di Kota Malang Berdasarkan Teori Doxiadis", Platonologi UNDIP Vol. 18, No. 4

Van Huijstee, M.M., Francken, M., Leroy, P., 2007. Partnerships for sustainabledevelopment: a review of current literature. Environ. Sci. 4 (2), 75-89

Vertakova, J., \& Plotnikov, V. (2014). Public-private Partnerships and the Specifics of their Implementation in Vocational Education. Procedia Economics and Finance, 16, 24-33.

Yescombe, E. R., \& Farquharson, E. (2018). What Are Public-Private Partnerships? PublicPrivate Partnerships for Infrastructure, 7-24.

\section{Newspaper article on website}

Widianto, Eko. 2016. “'Kampung Warna-warni” Malang, dulu 'Kumuh' Sekarang jadi Tempat Wisata" www.bbc.com

Murdaniangsih. Dwi, 2015”, “29 Kelurahan di Malang Kumuh”, www.nasional.republika.co.id

Sukarelawati, Endang. “Lima Wilayah Kota Malang rawanbencana”.21 Juli 2016.www.antaranews.com

Widianto, Eko. 2016. Kampung warna-warni" Malang, dulu 'kumuh' sekarang jadi tempat wisata https://www.bbc.com

Sofyan Arif Candra, Sofyan. 2017. https://jatim.tribunnews.com

Rezkisari, Indira. 2017. Mahasiswa Rancang Jembatan Kaca di Kampung Wisata Malang. https://www.republika.co.id

Asyari, Yusuf. Hari Bumi Hotel di Malang Bersih-bersih Kampung Jodipan. https://www.jawapos.com

Fauzian, Rizkie. Penataan Kawasan Kumuh Dukung Pengembangan Pariwisata. https://www.medcom.id 